\title{
Personal hygiene habits of some university students in Turkey
}

\section{Türkiye'deki bazı üniversite öğrencilerinin kişisel hijyen alışkanlıkları}

\section{Demet HANÇER-AYDEMIR ${ }^{1}$}

\section{ABSTRACT}

Objective: In this descriptive study, it was aimed to examine the personal hygiene habits of university students from Vocational School of Health Services, Suleyman Demirel University in Isparta and from School of Physical Education and Sports, Mehmet Akif Ersoy University in Burdur according to their departments, economic status (income) and sex variables.

Methods: While evaluating, respective scores were assigned to some hygiene behaviors and then "the total hygiene score" was calculated by adding up these scores in order to analyze how the students' hygiene behaviors changed with their descriptive qualities. The data obtained from research were analyzed using SPSS package program. In the statistical analysis of the data frequency (f), percentage (\%) and chi-square $\left(\mathrm{X}^{2}\right)$ analysis were applied in order to test the differences and $p<0,05$ was accepted significant.

Results: It was determined that the personal hygiene habits of the students who participated in the study did not differ according to the department variable and economic status (income) $(p>0.05)$. It was found that the personal hygiene habits of the students significantly differed according to sex; compared to the

\section{ÖZET}

Amaç: Tanımlayıcı nitelikte bir araștırma olan bu çalışmada; Isparta Süleyman Demirel Üniversitesi Sağlık Hizmetleri Meslek Yüksekokulu ile Burdur Mehmet Akif Ersoy Üniversitesi Beden Eğitimi ve Spor Yüksekokulu'nda öğrenim görmekte olan üniversite öğrencilerinin kişisel hijyen alıșkanlıklarının bölüm, ekonomik durum (gelir) ve cinsiyet değișkenlerine göre incelenmesi amaçlanmıștır.

Yöntem: Değerlendirme yapılırken öğrencilerin hijyenle ilgili davranışlarının tanımlayıcı özellikleri ile nasıl değiștiğini analiz edebilmek amacıyla hijyenle ilgili bazı davranışları için ayrı ayrı puan verilip bu puanlar toplanarak "toplam hijyen puanı" hesaplanmıștır. Araștırmanın verileri SPSS paket programı kullanılarak değerlendirilmiş, istatistiksel analizlerde frekans (f), yüzde (\%) ve farklılıkları test etmek için ise ki-kare $\left(\mathrm{X}^{2}\right)$ ișlemleri uygulanmıș ve $p<0,05$ değeri anlamlı kabul edilmiștir.

Bulgular: Araştırmaya katılan öğrencilerin kișisel hijyen alıșkanlıklarının bölüm değișkenine ve ekonomik gelir düzeylerine göre farklılık göstermediği tespit edilmiștir ( $p>0,05)$. Araștırmaya katılan öğrencilerin kișisel hijyen alıșkanlıklarının cinsiyete göre anlamlı farklıık gösterdiği belirlenmiș, erkek öğrenciler ile kıyaslandığı

${ }^{1}$ Suleyman Demirel University, Isparta Vocational School of Health Services, Medical Services and Techniques Department, Isparta

İletişim / Corresponding Author : Demet HANÇER-AYDEMIR Süleyman Demirel Üni. Isparta Sağlık Hizmetleri MYO Doğu Kampüsü 32260 Isparta - Türkiye Tel : +905066326409 E-posta/E-mail :demetaydemir@sdu.edu.tr

DOI ID : 10.5505/TurkHijyen.2019.04880

Hançer-Aydemir D. Personal hygiene habits of some university students in Turkey. Turk Hij Den Biyol Derg, 2020; 77(1): 87-96 
male students, the female students had significantly higher personal hygiene scores $(p<0.05)$. Consequently, it was found that the female students were more sensitive with regard to the personal hygienic practices and attached more importance to personal hygiene.

Conclusion: In the light of these results, it can be said that the personal hygiene behaviors of the male students should be improved and both families and teachers be responsible as regards this issue. In order to develop positive behavioral changes among students with regard to personal hygiene, seminars and conferences may be held by experts, various educative sources (posters, brochures, booklets etc.) involving practical hints may be provided for students, school staff and families; school counselling services may hold educative activities for students with regard to personal hygiene. Educative public service ads on personal hygiene may be broadcast on mass media especially on television.

Key Words: Hygiene, habits, health, students zaman kız öğrencilerin kișisel hijyen puanlarının anlamlı düzeyde daha yüksek olduğu tespit edilmiștir $(p<0.05)$. Sonuç olarak, kız öğrencilerin kișisel hijyen uygulamaları konusunda daha duyarlı oldukları ve kișisel temizliğine daha fazla önem verdikleri tespit edilmiștir.

Sonuç: Bu sonuçlara dayalı olarak; erkek öğrencilerin kişisel hijyen davranıșlarının geliștirilmesi gerektiği ve bunun için aile ve öğretmenlere görevler düștüğü, öğrencilerde kișisel hijyen ile ilgili olumlu davranıș değișikliklerinin geliștirilebilmesi amacıyla bu konuda uzman kişiler tarafından seminer ve konferanslar verilmesi, ilgili kurumlarca öğrencilere, okul personeline ve ailelere kișisel hijyen uygulamaları ile ilgili pratik bilgiler veren eğitici kaynaklar (afiș, broșür, el kitabı vb.) hazırlanarak sunulması, okullardaki rehberlik servislerinin kișisel hijyen konusunda okul personeli ve öğrencilere yönelik çalıșmalar yapması, özellikle televizyon olmak üzere uygun kitle iletișim araçlarında kișisel hijyen ile ilgili eğitici filmlerin kamu spotu olarak verilmesi önerilebilir.

Anahtar Kelimeler: Hijyen, alıșkanlıklar, sağlık, öğrenciler

\section{INTRODUCTION}

Self-care practices that individuals perform in order to maintain good health are termed personal hygiene. Hand cleaning, nail cleaning and care, face, eye and ear cleaning, hair care and cleaning, mouth and tooth care, foot cleaning, bathing regularly, good toilet habits and cleaning after toilet, wearing clean clothes and underwear, not sharing personal towel, hair brush, underwear, toothbrush and nail cutter etc. are all involved in personal hygiene concept (1, 2 ). Personal hygiene involves cleaning of the body through the removal of bodily secretions, wastes and transient microorganisms; providing a relaxation and comfort for the person; reducing muscle strain and removal of bad body odors (sweat odor), helping the individual to have a better appearance, improve self-confidence, improving and maintaining the skin health (3).

Hand cleaning is the most basic stage of personal hygiene. Hands and nails are the primary mechanisms through which microorganisms enter the body. Hands, which are in contact with the materials around all the time, carry bacteria, which may cause numerous diseases from the simple cold to some fatal diseases (4).

Some body secretions are removed with sweating through the skin and the sweat having evaporated, the solid waste is left on the skin surface. Bathing removes from the body sweat, fat, body secretions 
such as sebum, dead skin cells, some microorganisms and bad odors. If we do not have bathe regularly, the above-mentioned wastes are not removed, so bacteria growth on the skin increases and may cause many diseases. Besides, these wastes cause malodour (4). Bathing must be on a regular basis so that one's skin will remain clean. Under normal circumstances, an individual must have a bath at least twice a week. Factors such as individual choice, profession, climate conditions or having a skin which secrete too much sebum affect the frequency of a bath $(5,6)$.

Footcare and hygiene are among personal hygiene practices, too. Because feet become sweaty in shoes, they must be washed regularly; otherwise, malodor may disturb people around you and it may even lead to foot disorders. Therefore, feet must be washed with soapy water and dried. Cotton or woolen socks must be preferred depending on the season. These are quick-dry materials which absorb sweat. Socks must be changed everyday and it is important that one not wear another person's sock. If a person is not careful about his or her foot hygiene, fungal or bacterial infections may often occur (7).

One of the most important parts of personal hygiene is mouth and dental health. The most effective way to protect our teeth is to brush them regularly. Leftover food remaining in your mouth after a meal breed harmful bacteria. A toothbrush is a personal tool of hygiene; therefore, you must not use another person's toothbrush. Toothbrushes must be changed every three to four months or every six months at the latest (4).

Especially, in places where you have to share a toilet or bathroom, personal hygiene is of great importance Personal hygiene practices are basic to the prevention of many diseases, notably contagious diseases $(8,9)$. At present, infectious diseases are among the diseases which occur and are deadly most (10). It is pointed out in the public health literature that 40 to 50 diseases may be prevented from spreading through the improvement of personal hygiene $(11-14)$. It is pointed out in the study by
Aiello et al. (13) that $31 \%$ of gastrointestinal diseases and $21 \%$ of respiratory infections may simply be prevented through handwashing.

Personal hygiene habits and behaviours may be influenced by many factors such as beliefs, values, habits, body image, socio-economic and cultural background, knowledge level, individual choices, diseases and physiological periods (menstruation, pregnancy, puerperality etc.), familial tendencies, the physical and social circumstances of the place where he lives or works. Therefore, every individual's hygiene habits are different (3, 15-17).

Although there are many studies on the personal hygiene habits of pupils from primary schools $(1,2,8$, $9,18-23)$, there are very few studies on the personal hygiene habits of university students in the literature (24-26).

Health care-associated infections continue to be a threat to hospital patients. Personal hygiene practices of health-care personnel are the simplest and most effective measure for preventing nosocomial infections and cross-infections (12). Sports activities are also one of the practices affecting hygiene habits. Sport activities supply oxygen and nutritions to the muscles, and they remove the affluents from the body. These affluents gather on the skin which gets dirty very quickly. People should take a bath in order to get rid of dirts and other microorganisms on the skin, dermal pores and surface cells rashs (8). In this respect, it is necessary to make programs that educate health profession and physical education teachers more conscious about personal hygiene. Therefore, in this study, two different college students who were trained as health technicians and physical education and sports teachers were targeted. In this study, it was aimed to examine the personal hygiene habits of university students from Isparta Vocational School of Health Services, Suleyman Demirel University in Isparta and from School of Physical Education and Sports, Mehmet Akif Ersoy University in Burdur according to their departments, economic status (income) and sex variables. 


\section{MATERIAL and METHOD}

This descriptive study involved a total of 209 volunteer students (49\% of target population) from Isparta Vocational School of Health Services, Suleyman Demirel University in Isparta and from School of Physical Education and Sports, Mehmet Akif Ersoy University in Burdur. The data in the study were collected by means of questionnaire by the researcher in April 2015 and official permission was gained from the schools so that the study could be conducted. The study was conducted based on voluntariness and only those students who agreed to fill in a questionnaire form were involved in the study. Names and other identity information were not included in the forms and the study was conducted during the weekdays when there were not any exams. Likewise the years of education of the students participating in the study are not noted. The students were informed about the study prior to the application. Verbal consent was obtained from the students and they were informed about the study prior to the application.

According to the importance of the hygiene habit, scores of 1, 2, 3 and 4 were given to each desired positive behavior in the questionnaire form. The other answers given for each question were rated as ' 0 '. In order to analyze how the students' hygiene habits change depending on the descriptive characteristics, "total hygiene score" was calculated. Each hygiene habit was scored and these were added up to obtain the total hygiene score. And, a scale with a scoring range of 8 to 25 points. Poor score was considered to be a score $<10$, and other scores categorized as good score 10-15, very good score $16-20$ and excellent score $>20$. Scores for each hygiene habit are seen in Table 1 (27).

In the question form, which includes 11 questions, the first 3 question aim to find out descriptive qualities (department, sex, economic income) whereas the other eight aim to find out information related to personal hygiene habits. The questions aimed to find out hand washing, foot washing, bathing, underwear changing, sock changing and tooth brushing frequency.

Statistical analyses were performed using SPSS software, version 16.0 (Statistical Package for Social Sciences Inc., Chicago, IL, USA). In the statistical analyses, (f) represents frequency, (\%) represents percentage. Chi-square $\left(\mathrm{X}^{2}\right)$ procedures were applied in order to test the differences and $p<0,05$ was accepted significant.

\section{RESULTS}

While $71.3 \%$ of the participants were from Isparta Vocational School of Health Services, 28.7\% of them were from School of Physical Education and Sports. While $56.9 \%$ of the participants were female, $43.1 \%$ were male. The $24.4 \%$ of the participants had a family with a good income, $62.7 \%$ of them were from middle-income families; and $12.9 \%$ were from families with a low income (Table 2).

When the personal hygiene scores were analyzed according to the participant student's departments, it was determined that the personal hygiene habits did not alter according to the department variable ( $p>0.05$ ) (Table 3).

It was determined that the personal hygiene habits of the participants did differ significantly according to sex. Compared to the male students, the female students had personal hygiene scores significantly higher than the males $(p<0.05)$ (Table 4$)$.

When the personal hygiene scores of the participants were analyzed according to their economic income level, it was found that personal hygiene habits did not differ according to economic income levels ( $p>0.05)$ (Table 5).

\section{DISCUSSION}

In this study, which investigates the personal hygiene habits of some students who study at Isparta Vocational School of Health Services, Suleyman 
Table 1. The scores included while calculating the total hygiene score on some hygiene habits of the students

\begin{tabular}{|c|c|c|c|}
\hline Some Habits Related to Hygiene & Scoring & Some Habits Related to Hygiene & Scoring \\
\hline Number of hand washing/day & & Frequency of feet washing & \\
\hline 1 to 3 times & 1 & Fewer than one a day & 1 \\
\hline 4 to 6 times & 2 & Once a day & 2 \\
\hline 7 to 9 times & 3 & More frequent than 1 a day & 3 \\
\hline 10 or over. & 4 & & \\
\hline Duration of handwashing & & Socks changing frequency & \\
\hline$<1$ minute & 1 & Once every three days or less frequent & 1 \\
\hline 2 to 3 minutes & 2 & Every two days & 2 \\
\hline$>4$ to 5 minutes & 3 & Once a day or more frequent & 3 \\
\hline Frequency of bathing & & Frequency of tooth brushing & \\
\hline Once or twice a week & 1 & Once a day & 1 \\
\hline 3 to 6 times a week & 2 & Twice a day & 2 \\
\hline Everyday or twice a day & 3 & 3 times or more a day & 3 \\
\hline Frequency of changing underwear & & Frequency of changing a toothbrush & \\
\hline Once or twice a week & 1 & Every six months or less frequent & 1 \\
\hline Every other day & 2 & Every 2 to 5 months & 2 \\
\hline Everyday or twice a day & 3 & Once a month & 3 \\
\hline
\end{tabular}

Table 2. The distribution of the participants according to their department, sex and economic income levels

\begin{tabular}{|c|c|c|c|}
\hline & & $\mathrm{n}$ & $f$ \\
\hline \multirow{3}{*}{ Department } & Isparta Vocational School of Health Services & 149 & 71.3 \\
\hline & School of Physical Education and Sports & 60 & 28.7 \\
\hline & Total & 209 & 100.0 \\
\hline \multirow{3}{*}{ Sex } & Female & 119 & 56.9 \\
\hline & Male & 90 & 43.1 \\
\hline & Total & 209 & 100.0 \\
\hline \multirow{4}{*}{ Economic income level } & Good & 51 & 24.4 \\
\hline & Middle & 131 & 62.7 \\
\hline & Low & 27 & 12.9 \\
\hline & Total & 209 & 100.0 \\
\hline
\end{tabular}


Table 3. The comparison of the participants' personal hygiene scores according to their departments

\begin{tabular}{|c|c|c|c|c|c|c|}
\hline \multirow[b]{2}{*}{ Department } & \multirow[b]{2}{*}{$\begin{array}{l}\text { Frequency and } \\
\text { percent value }\end{array}$} & \multicolumn{3}{|c|}{ Hygiene score } & \multirow[b]{2}{*}{$X^{2}$} & \multirow[b]{2}{*}{$\mathrm{p}$} \\
\hline & & $\begin{array}{c}10 \text { to } 15 \\
\text { points }\end{array}$ & $\begin{array}{c}16 \text { to } 20 \\
\text { points }\end{array}$ & $\begin{array}{c}21 \text { points and } \\
\text { over }\end{array}$ & & \\
\hline Isparta Vocational School of & $f$ & 37 & 91 & 21 & \multirow{6}{*}{2.230} & \multirow{6}{*}{.328} \\
\hline Health Services & $\%$ & 24.8 & 61.1 & 14.1 & & \\
\hline School of Physical & $f$ & 20 & 30 & 10 & & \\
\hline Education and Sports & $\%$ & 33.3 & 50.0 & 16.7 & & \\
\hline \multirow{2}{*}{ Total } & $f$ & 57 & 121 & 31 & & \\
\hline & $\%$ & 27.3 & 57.9 & 14.8 & & \\
\hline
\end{tabular}

Table 4. The comparison of the personal hygiene scores of the participants according to sex

\begin{tabular}{|c|c|c|c|c|c|c|}
\hline \multirow[b]{2}{*}{ Sex } & \multirow{2}{*}{$\begin{array}{c}\text { Frequency } \\
\text { and percent value }\end{array}$} & \multicolumn{3}{|c|}{ Hygiene score } & \multirow[b]{2}{*}{$\mathrm{X}^{2}$} & \multirow[b]{2}{*}{$\mathrm{p}$} \\
\hline & & 10 to 15 points & 16 to 20 points & $\begin{array}{c}21 \text { points and } \\
\text { over }\end{array}$ & & \\
\hline \multirow{2}{*}{ Female } & $f$ & 21 & 78 & 20 & \multirow{6}{*}{12.909} & \multirow{6}{*}{.002} \\
\hline & $\%$ & 17.6 & 65.5 & 16.8 & & \\
\hline \multirow{2}{*}{ Male } & $f$ & 36 & 43 & 11 & & \\
\hline & $\%$ & 40.0 & 47.8 & 12.2 & & \\
\hline \multirow{2}{*}{ Total } & $f$ & 57 & 121 & 31 & & \\
\hline & $\%$ & 27.3 & 57.9 & 14.8 & & \\
\hline
\end{tabular}

Table 5. The comparison of the personal hygiene scores of the participants according to their economic income levels

\begin{tabular}{|c|c|c|c|c|c|c|}
\hline \multirow{2}{*}{$\begin{array}{l}\text { Economic income } \\
\text { level }\end{array}$} & \multirow{2}{*}{$\begin{array}{l}\text { Frequency and } \\
\text { percent value }\end{array}$} & \multicolumn{3}{|c|}{ Hygiene score } & \multirow[b]{2}{*}{$X^{2}$} & \multirow[b]{2}{*}{$p$} \\
\hline & & $\begin{array}{l}10 \text { to } 15 \\
\text { points }\end{array}$ & $\begin{array}{l}16 \text { to } 20 \\
\text { points }\end{array}$ & $\begin{array}{c}21 \text { points and } \\
\text { over }\end{array}$ & & \\
\hline \multirow{2}{*}{ Good } & $f$ & 15 & 24 & 12 & \multirow{8}{*}{6.886} & \multirow{8}{*}{.142} \\
\hline & $\%$ & 29.4 & 47.1 & 23.5 & & \\
\hline \multirow{2}{*}{ Middle } & $f$ & 32 & 82 & 17 & & \\
\hline & $\%$ & 24.4 & 62.6 & 13.0 & & \\
\hline \multirow{2}{*}{ Low } & $f$ & 10 & 15 & 2 & & \\
\hline & $\%$ & 37.0 & 55.6 & 7.4 & & \\
\hline \multirow{2}{*}{ Total } & $f$ & 57 & 121 & 31 & & \\
\hline & $\%$ & 27.3 & 57.9 & 14.8 & & \\
\hline
\end{tabular}


Demirel University in Isparta and School of Physical Education and Sports, Mehmet Akif Ersoy University in Burdur, it was determined that the personal hygiene habits of the participants did differ significantly according to sex; compared to the male students, the female students were found to have significantly higher personal hygiene scores $(p<0.05)$. The findings from this study are similar to those in a study conducted by Kaya et al. (1) among 9th and 10th graders at a highschool in Ankara in order to determine thepersonal hygiene habits. Şimșek et al. (27) and Kırım and Hırça (28) conducted respective studies on high-school students and did not find a significant difference between the hygiene habits of the male and the female students. In other studies in which the personal hygiene habits of the students were investigated, the female students were found to be more sensitive as to hygiene habits such as handwashing and face washing in the morning, handwashing after meals, washing fruits or vegetables before eating, brushing teeth after breakfast, changing socks everyday and bathing more frequently $(1,25-27)$. Şimșek et al. (27) evaluated the results they found and pointed out that this was a reflection the behavioral patterns on the female students' part as a result of the society's expectation of them and added that this fact could lead to the males being characterized as the risk group because of the diseases which might emerge as a result of their inadequate hygiene.

Hands are the organs which have the most contact with the environment and thus the dirtiest in everyday life. Handwashing is the easiest, most effective and least costly way to prevent diseases (29). Anderson et al. (30) tried to determine the handwashing habits of the students at a university through observation. According to the results of this study, in which 1400 observations were done over a period of three weeks, $58.3 \%$ of the students were careful about their hand hygiene. In the same study, it was found that the female students washed their hands more often compared to the male students. In a study by Miko et al. (31), the female students (55.3\%) were found to wash hands five times or more a day compared to the male students (41.3\%) . Handwashing after toilet use was observed among the students in a study conducted by De Alwis et al. (32) on Malaysian medical students. As it was in the other studies, it was observed that the female students washed their hands more often and that the amount of bacteria on the door handle of the male rest room was more in number than those on the female rest room's door handle. It is possible to conclude that the female students are more sensitive about hand and foot hygiene compared to the male students according to the findings obtained in these studies.

People must have a bath as often as possible in order to remove parasites, dirt, dead cells and other compounds accumulated on the surface of the skin and to open skin pores. Bathing is not only important in terms of hygiene but also in terms of personal psychology. It contributes to general personal wellbeing and happiness (7). In a study by Arat et al. (33), it was determined that the female students washed their hair $(p<0.05)$ and had baths more often in winter $(p<0.05)$ compared to the male students. Again, in the same study, it was found that there was a significant difference $(0.01)$ in favor of the female students as to the frequency of underwear and clothes and according to the comparison of hand hygiene in terms of sex it was found out that the female students washed their hands more often upon returning home from school $(p<0.05)$. According to the results of this study, it may be concluded that the female students are more sensitive about body hygiene and care compared to the male students. It was determined in other studies conducted on students' personal hygiene habits that the female students, compared to the male students, were better as to body hygiene and were found to have baths more often $(1,26,27,29,31)$.

Today, one of the most important public health concerns is dental cavities. It is pointed out that prevention of periodontal diseases is more important than treatment and the easiest way of which is to have 
a good oral hygiene. In a study by Arat et al. (33), it was found out that there was a significant difference in favor of female students as to the frequency of tooth brushing according to sex $(p<0.05)$. When other studies were analyzed, it was observed that the female students were more sensitive about tooth brushing compared to the male students $(25,34)$.

In this study, after examining the personal hygiene scores of the participants according the department, it was determined that department variable did not have an impact on personal hygiene habits $(p>0.05)$. However, it is among the striking findings in our study that while it was expected that the students from Isparta Vocational School of Health Services to have higher scores than those from School of Physical Education and Sports, it was seen that they had similar hygiene scores. Isparta Vocational School of Health Services students are expected to be role models by the nature of their occupational position and therefore, such an expectation that they should have higher scores is only natural. The fact that there were not any significant differences between personal hygiene scores according to schools students study at is in contradiction with the findings that "the average personal hygiene scores of students from Health Vocational High School is lower compared to those of the students from general high-schools" presented by Şimșek et al. (27). Karaoğlu and Pehlivan (35) attributed this to the fact the courses the students were studying did not have much positive effect on their knowledge and practice level, which meant that the courses did not reach the goal. Coşgun and Kara (36) determined that positive behavioral changes observed among the students after the hygiene training given to some secondary students was not much compared to the increase in their knowledge level. In their opinion, students' knowledge, attitude and behaviors related to health may be influenced positively through a health training. However, the fact that behavioral changes require a longer time to happen necessitate that health education at schools must be permanent and instructors must be supportive of students about good hygiene habits and be role models for them. This finding explains why students from a medical vocational high-school did not have the expected level of hygiene scores.

When the personal hygiene scores of the students taking part in the study were analyzed according to their economic income level, it was found that the personal hygiene habits did not differ according to their economic income level ( $p>0.05)$. In another study conducted in two schools which were of different socioeconomic status in Ankara, it was found out that the students from one of the schools, which was located in a quarter with a relatively higher socio-economic status generally washed their hands more often than those who were studying at the other school, which was located in a socio-economically low quarter (18). In a study by Doğan (37), 50 elementary school pupils were examined for coliforms, which are the indicator of fecal contamination and it was determined that the socio-economically low group had significantly more contamination. These results do not have any resemblance to the ones we obtained in our study. The findings in this study are not close to the ones obtained in ours. This fact makes one think that the health education which university students are given in high-school or primary school contributes positively to personal hygiene habits independent of the socioeconomic background. However, both in this study and the others reviewed indicate that students do not have adequate knowledge as to personal hygiene and it is essential that hygiene practices, which the foremost behaviors required to prevent diseases, be developed and improved.

Personal care and hygiene are one of the most important circles in the cleaning chain which spreads from the individual to the general. In order to prevent cross contamination in common areas, to be good in relation between people, to feel good, and to have a positive external appearance, both healthcare technicians and sportsmen should give importance to personal hygiene. Particularly intense 
physical activity in the sportsmen causes the amount of sweat coming out of the body to increase. In this case, bathing should be done and underwear should be changed. In the light of all this information, it is concluded that training programs about hygiene must be planned and given so that students studying at the schools where our study was conducted can adopt positive personal hygiene habits. Such training programs must be more comprehensive and take longer periods especially in areas with a low socioeconomic level where good hygiene practices are usually inadequate.

To conclude with, female students are more sensitive as to personal hygiene practices compared to male students. On this basis, it may be suggested that the personal hygiene habits of male students be improved and both families and teachers be responsible as regards this issue. In order to develop positive behavioral changes among students with regard to personal hygiene, seminars and conferences may be held by experts, various educative sources (posters, brochures, booklets etc.) involving practical hints may be provided for students, school staff and families; school counselling services may hold educative activities for students with regard to personal hygiene. Educative public service ads on personal hygiene may be broadcast on mass media especially on television. In addition to these, whether positive personal hygiene habits are developing at schools must be monitored, which, we think, might also enhance desired hygiene behaviors.

\section{REFERENCES}

1. Kaya $M$, Büyükșerbetçi $M$, Meriç $M B$, Çelebi $A E$, Boybeyi Ö, Ișı A, et al. Ankara'da bir lisenin 9. ve 10. sınıf öğrencilerinin kișisel hijyen konusunda davranıșlarının belirlenmesi. STED, 2006; 15 (10): 179-83.

2. Aslan D, Mermerkaya MU, Kaya FE, Kaya H, Esen E, Koban Y, et al. Ankara'da bir ilköğretim okulunda el yıkama konusunda yapılmıș olan bir müdahale çalıșması. J Med Sci, 2006; 26 (2): 157-62.

3. Ulusoy MF, Görgülü RS. Hemşirelik Esasları-Temel Kuram, Kavram İlke ve Yöntemler. 3. Baskı. Ankara: TDFO LTD. Ștd, 1997.

4. Bilici S. Ilköğretim çocukları için el hijyeni. Ankara: Sağlık Bakanlığı-Temel Sağlık Hizmetleri Genel Müdürlüğü, 2008.

5. Güler Ç. Hijyen, çevre ve halk sağlığı. 1. Ulusal Ev Idaresi Kongresi. 21-23 Ekim, Ankara. 1998.

6. Ulusoy MF, Görgülü RS. Hemșirelik Esasları-Temel Kuram, Kavram İlke ve Yöntemler. 5. Baskı. Ankara: 72 TDFO Ltd. Ști., 2001.

7. Güler Ç. Kișisel hijyen. TSK Kor Hek Bül, 2004; 3 (6): 119-32.
8. Önsüz MF, Hıdıroğlu S. İstanbul'daki farklı iki ilköğretim okulundaki öğrencilerin kișisel hijyen alıșkanlıklarının belirlenmesi. Adnan Menderes Üni Tip Fak Derg, 2008; 9 (1): 9-17.

9. Yılmaz E, Özkan S. Bir ilçede farklı yerleșim yerindeki ilköğretim okulu öğrencilerinin kișisel hijyen alıșkanlıklarının karșılaștırılması. Fırat Sağ Hiz Derg, 2009; 4 (10): 1-18.

10. Nenstiel RO, White GL, Aikans T. Clinical alert: handwashing-a century of evidence ignored. Clin Rev, 1997; 7 (1): 55-8.

11. Grene VW. Personal hygiene and life expectancy improvements since 1850: historic and epidemiologic associations. Am J Infect Control, 2001; 29: 203-6.

12. Pittet D. Improving adherence to hand hygiene practice: a multidisciplinary approach. Emerg Infect Dis, 2001; 7: 234-40.

13. Aiello AE, Coulborn R, Perez V, Larson EL. Effect of hand hygiene on infectious disease risk in the community setting: a meta-analysis. Am J Public Health, 2008; 98 (8): 1372-82.

14. Ejemot RI, Ehiri JE, Meremikwu MM, Critchley JA. Hand washing for preventing diarrhoea. Evid.Based Child Health, 2009; 4: 893-939. 
15. İnanç N, Hatipoğlu S, Yurt V, Avcı E, Akbayrak N. Hemşirelik esasları. Ankara: GATA Hastanesi, 1994.

16. Akșit B. Toplum, Kültür ve Sağlık. Bertan M, Güler C, ed. Halk sağlığı temel bilgiler içinde. II. Baskı. Ankara: Güneș Kitabevi Ltd. Şti., 1995. s. 15-25.

17. Görgülü RS. Hijyen ve sağlığımız. Actual Med, 2000; 8 (11): 36-43.

18. Güleç M, Topbaș M, Kır T, Hadse M. Ankara'da sosyoekonomik düzeyi farklı iki yerleșim yerindeki iki ilköğretim okulunda seçilen öğrencilerde el yıkama alıșkanlıkları. Türk Hij Den Biy Derg, 2000; 57: 71-6.

19. Guinan M, Mc Guckin M, Ali Y. The effect of a comprehensive handwashing program on absenteeism in elementary schools. Am J Infect Control, 2002; 30 (4): 217-20.

20. Örsal Ö, Tezcan S, Çakır B, Tokur M, Gülmez G. Öğrencilerin kișisel temizlik bilgileri ve durumlarının değerlendirilmesi. 8. Ulusal Halk Sağlığı Kongresi. 23-28 Eylül, Diyarbakır. 2002.

21. Can G, Topbaș M, Kapucu M. Trabzon'da iki farklı yerleșim yerindeki ilköğretim öğrencilerinin kișisel hijyen alıșkanlıkları. TSK Koruyucu Hekimlik Bülteni, 2004; 3 (8): 170-7.

22. Çetinkaya S, Arslan S, Nur N, Demir ÖF, Özdemir L, Sümer H. Sivas il merkezi'nde sosyoekonomik düzeyi farklı üç ilköğretim okulu öğrencilerinde kișisel hijyen alıșkanlıkları. Sürekli Tıp Eğitimi Dergisi, 2005; 14 (10): 229- 36.

23. Kaya M, Aslan D. Ankara'da bir ilköğretim okulunda el yıkama konusunda bir müdahale çalıșması. Erciyes Tıp Dergisi, 2009; 31 (2): 135-143.

24. Wong TW, Wai-San Tam W. Handwashing practice and the use of personal protective equipment among medical students after the SARS epidemic in HongKong. Am J Infect Control, 2005; 33 (10): 580-6.

25. Yetkin A, Yiğitbaș Ç. Sağlık yüksekokulu birinci ve dördüncü sınıf öğrencilerinin bireysel hijyen ile ilgili alıșkanlıklarının karșılaștırılması. Atatürk Üni Hemșir Yüksekokul Derg, 2008; 11 (2): 71-84.

26. Erkal S, Şahin H. An application on determining hygiene behaviors of university students. Int J Bus Soc Sci, 2011; 2 (8): 170-6.
27. Şimşek Ç, Piyal B, Tüzün H, Çakmak D, Turan $\mathrm{H}$, Seyrek V. Ankara il merkezindeki bazı lise öğrencilerinde kișisel hijyen davranıșları. TSK Kor Hek Bül, 2010; 9 (5): 433-40.

28. Kırım C, Hırça N. Lise öğrencilerinin kișisel hijyen ve temizlik alıșkanlıklarının fen okur-yazarlığına göre değerlendirilmesi. Bartın Üni Eğitim Fak Derg, 2015; 4 (2): 790-802.

29. Üner S, Sevencan F, Bașaran E, Balcı C, Bilaloğlu B. Bir sağlık ocağına bașvuran kișilerin sosyal el yıkama ile ilgili bazı bilgi ve tutumların saptanması. TSK Kor Hek Bül, 2009; 8 (3): 207-16.

30. Anderson JL, Warren CA, Perez E, Louis RI, Phillips $\mathrm{S}$, Wheeler J, et al. Gender and ethnic differences in hand hygiene practices among college students. Am J Infect Control, 2008; 36 (5): 361-8.

31. Miko BA, Cohen B, Conway L, Gilman A, Seward SL, Larson E. Determinants of personal and household hygiene among college students in New York City. Am J Infect Control, 2011; 40: 940-5.

32. De Alwis WR, Pakirisamy P, San LW, Xiaofen EC. A study on hand contamination and hand washing practices among medical students. ISRN Public Health, 2012; 1-5

33. Arat A, Şimșek I, Erdamar G. Yatılı ilköğretim bölge okulu II.kademe öğrencilerinin kișisel hijyen uygulamaları. Gazi Üniv Endüst Sanat Eğit Fak Derg, 2014; 33: 58-72.

34. Taani DS, al-Wahadni AM, al-Omeri M. The effect of frequency of toothbrushing on oral health of 14-16 years old. J Irish Dent Assoc, 2003; 49: 15-20.

35. Karaoğlu L, Pehlivan E. Malatya il merkezinde farklı programlardaki lise son sınıf öğrencilerinin sağlıkla ilgili bilgi, tutum ve uygulamalarının incelenmesi. Turgut Özal Tıp Merk Derg, 1997; 4 (4): 391-8.

36. Coșgun $M$, Kara F. Öğrencilere verilen sağlık eğitiminin bilgi ve davranışlarına etkisinin değerlendirilmesi. Sürekli Tıp Eğit Derg, 2015; 24 (2): 55-63.

37. Doğan F. Farklı sosyo-ekonomik düzeyindeki ilkokul çocuklarında el kirliliği araștırması. Ege Tıp Dergisi, 1991; 30 (2): 264-6. 